\title{
HEPATOTOXICITY OF BISPHENOL A UNDER CONDITIONS OF DIFFERENTIAL SUPPLEMENTATION WITH RETINOIDS
}

\author{
I. O. SHMARAKOV, V. L. BORSCHOVETSKA, \\ L. P. IVANISHCHUK, M. M. MARCHENKO \\ Yuriy Fed'kovych Chernivtsi National University, Ukraine; \\ e-mail: igor.shmarakov@gmail.com
}

\begin{abstract}
Classical xenoestrogenic in vivo effects of bisphenol A (2,2-bis(4-hydroxyphenyl)propane, BPA) are well-described in the literature, however the molecular mechanisms of BPA-induced hepatotoxicity are not fully characterized. The work is aimed to assess biochemical markers of BPA induced hepatotoxicity under conditions of differential supplementation with retinoids. We demonstrate that the absence of hepatic retinyl esters as the main form of vitamin A storage provides for a resistance to BPA induced liver damage. Retinoid supplementation increases the hepatotoxic effects of bisphenol $A$, evidenced in higher indexes of oxidative damage of lipids, proteins and non-protein thiol groups as well as increase of serum alanine aminotransferase activity and myeloperoxidase activity in liver parenchyma. The absence of hepatotoxicity signs when hepatic retinoid stores are depleted and their presence during normal or excessive retinoid supplementation suggest that hepatic retinoid availability is one of the factors determining the hepatotoxicity of bisphenol A.
\end{abstract}

Key word s: retinoids, bisphenol A, hepatotoxicity, xenobiotics.

$\mathrm{H}$ epatotoxicity is currently one of the primary targets for biomedical research due to ever increasing toxic pressure on liver as an organ of homeostasis and detoxification [1]. The adequate experimental models are indispensable for better understanding of biochemical mechanisms of hepatotoxicity progression and for development and testing of novel approaches to counteract this pathology [2]. Bisphenol A (2,2-bis(4-hydroxyphenyl)propane, BPA) is one of the potential in vivo hepatotoxicity inducer and is widely used as a monomer for polycarbonate productions [3]. There is a worrying constant danger of chronic human exposure to low-level doses of BPA due to its leaching from BPA-containing household products (plastic containers, compact disks, DVDs, protective and corrective eyewear etc.) [4]. The classical toxic effects of BPA are primarily determined by its xenoestrogenic qualities due to similarities between chemical structure of BPA and 17- $\beta$ estradiol resulting in high affinity binding with estrogen receptors $[5,6]$. Although toxic xenoestrogenic effects of BPA are described in detail, the molecular mechanisms behind BPA-induced hepatotoxicity are still poorly understood and require further study. The detoxification of this xenobiotic, primarily in liver, generates highly reactive bisphenol metabolites and activates free-radical processes [7].

Retinoids, including vitamin A and its metabolites (retinyl esters, retinol, retinoic acid) [8] may modulate toxicity of xenobiotics. Numerous studies $[9,10]$ prove that retinoids control liver detoxification system through regulation of expression of cytochrome $\mathrm{p} 450$ isoforms by binding to nuclear retinoic acid receptor (RAR $\alpha, \beta, \gamma$ ) and retinoid $\mathrm{X}$ receptors (RXR $\alpha, \beta, \gamma)$ [11]. Since CYP-mediated metabolism of xenobiotics may produce more toxic highly reactive intermediates, the substances that can affect the activity of detoxification system may define toxicity of xenobiotics. It is thus sensible to investigate BPA toxicity under differential supplementation with retinoids.

The aim of this work was to evaluate the biochemical parameters of BPA-induced hepatotoxicity under differential supplementation with retinoids.

\section{Materials and Methods}

The experimental animals were C57BL/6J mice (wild type, WT) of 2.5-3 month age, with body mass of 20-25 g. The animals, which are from a congenic subline of C57 mice, were kindly provided by prof. W. Blaner from the Institute of Human Nutrition, 
Columbia University, New York (USA). Animal handling and manipulation was conducted in accordance with the article 26 of the Law of Ukraine No 3447IV 21.02.2006 "On the protection of animals from cruelty", "The European Convention for the Protection of Vertebrate Animals used for Experimental and Other Scientific Purposes" (Strasbourg, 1986), "General Ethical Considerations for Animal Experimentation" established by First Ukrainian Congress on Bioethics, and with regard to NIH Guide for the Care and Use of Laboratory Animals [12]. We used hexadecyltrimethylammonium bromide, o-dianisidine dihydrochloride, 2,4-dinitrophenylhydrazine (DNPH), ethylenediaminetetraacetic acid (EDTA) by Sigma-Aldrich (USA), 5,5'-dithiobis-(2nitrobenzoic acid (Ellman's reagent) by LOBA (Austria), trichloroacetic acid by SHANGHAI SYNNAD (China). All the other reagents were of local manufacture, of purity equal or above 'pure for analysis'.

BPA was diluted in corn oil (used as vehicle) and given orally daily for 3 days in doses of $50 \mathrm{mg} /$ $\mathrm{kg}$ of body mass, corresponding to the lowest observable adverse effect level (LOAEL) dosage [13].

We used the following methodology to investigate BPA hepatotoxicity under differential supplementation with retinoids:

- Depletion of hepatic vitamin A stores (as retinyl esters) was modeled by usage of C57BL/6J transgenic mice that are unable to store retinyl esters due to knockout of lecithin:retinol acyltransferase (EC 2.3.1.135) gene $\left(\mathrm{Lrat}^{-/}\right)$, their phenotype has been characterized thoroughly [14];

- Vitamin A overconsumption was modeled by gavage of retinyl acetate (Rac) in a very high dose of $3000 \mathrm{IU}$ at $12 \mathrm{~h}$ intervals for 3 days (the physiological dose is $30 \mathrm{IU})$ [15].

The animals were divided into the following groups (5 to 6 animals per group):

- Group I (control group I) - wild type animals receiving the vehicle alone;

- Group II (experimental group I) - wild type animals receiving $50 \mathrm{mg} / \mathrm{kg}$ of BPA per os;

- Group III (experimental group II) - wild type animals receiving $50 \mathrm{mg} / \mathrm{kg}$ of BPA and $3000 \mathrm{IU}$ of retinyl acetate per os;

- Group IV (control group II) - $\mathrm{Lrat}^{-/}$animals receiving the vehicle alone;

- Group V (experimental group III) - rrat $^{-1}$ animals receiving $50 \mathrm{mg} / \mathrm{kg}$ of BPA per os;
- Group VI (experimental group IV) - rrat $^{-/-}$ animals receiving $50 \mathrm{mg} / \mathrm{kg}$ of BPA and $3000 \mathrm{IU}$ of retinyl acetate per os.

Toxic lesions of liver were evaluated biochemically $72 \mathrm{~h}$ after start of the experiment. The animals were euthanized under light ether anesthesia. The liver was excised and blood collected from inferior vena cava. Blood serum was obtained by centrifugation at $1500 \mathrm{~g}$ for $15 \mathrm{~min}$.

The extent of liver lesions was assayed through catalytic activity of alanine aminotransferase (ALT, EC 2.6.1.2) in blood serum by Reitman and Frankel method kit (Felicit Diagnostika, Dnipro, Ukraine) and expressed as IU/L. Myeloperoxidase activity (MPO, EC 1.11.1.7) as an indicator of inflammatory infiltration of hepatic tissue was assayed as has been described [16] and expressed as $\Delta \mathrm{D} \times \mathrm{min}^{-1} \times \mathrm{mg}^{-1}$ of protein.

Oxidative degradation of liver biomolecules was assayed as content of thiobarbituric acid-reactive substances (TBARS), protein carbonyl groups, protein and non-protein thiol groups. TBARS level was assayed after method [17] that is based on reaction between these substances and thiobarbituric acid, the resulting absorbance was measured at $\lambda=532 \mathrm{~nm}\left(\varepsilon=1.56 \times 10^{5} \mathrm{~cm}^{-1} \times \mathrm{M}^{-1}\right)$. TBARS content was expressed as nmol/mg of protein. Protein thiol groups content was assayed after method [18], which is based on reaction of protein carbonyls with $\mathrm{DNPH}$, the resulting absorbance was measured at $\lambda=370 \mathrm{~nm}\left(\varepsilon=21 \times 10^{3} \mathrm{~cm}^{-1} \times \mathrm{M}^{-1}\right)$. Carbonyl groups level was expressed as nmol/mg of protein. Protein and non-protein thiol groups in liver were assayed by reaction with Ellman's reagent that produces yellow hued 2-nitro-5-thiobenzoate anion, the intensity of color is proportional to thiol content [19, 20]. Protein and non-protein thiols were separated by sedimentation in $20 \%$ trichloroacetic acid. The content was expressed as $\mathrm{nmol} / \mathrm{mg}$ of protein.

Protein concentration was determined by Lowry method [21].

Statistical data processing was done with Microsoft Excel software using one-way analysis of variance followed by Tukey's honest significant difference test. The differences were considered significant if $P \leq 0.05$. In graphic representation, the values are indicated by Latin letters $(a, b, c)$ if the differences between them are significant, e.g. values indicated by $a$ differ significantly from those indi- 
cated by $b$ and $c$. Values indicated by the same letter do not differ significantly.

\section{Results and Discussion}

The results of our studies demonstrate that BPA administration to wild type animals ( sufficient with regards to their hepatic retinoid stores) caused symptoms of hepatotoxicity to manifest on $72^{\text {nd }} \mathrm{h}$ of experiment. This is evidenced by 1.6 -fold increase in blood serum ALT activity and twofold increase in hepatic MPO activity as a consequence of freeradical processes elevation, due to primarily BPA metabolism [22].

We observed no significant differences in blood serum ALT activity and hepatic MPO activity of animals with no hepatic retinoid stores ( $\mathrm{Lrat}^{-/}$animals) in comparison with those of control animals (Fig. 1), indicating that BPA administration to $\mathrm{Lrat}^{-/-}$animals did not cause liver lesions. On the other hand, the administration of $3000 \mathrm{IU}$ of vitamin A to such animals (deprived with endogenous retinoid stores) caused 61\% increase in ALT and 6-fold increase in MPO in comparison to animals administered with BPA. This evidences onset of hepatotoxicity that is dependent on availability of retinoids. Comparatively, administration of very high doses of vitamin A to wild-type animals caused the BPA-induced liver lesions to become more severe, expressed as twofold

A

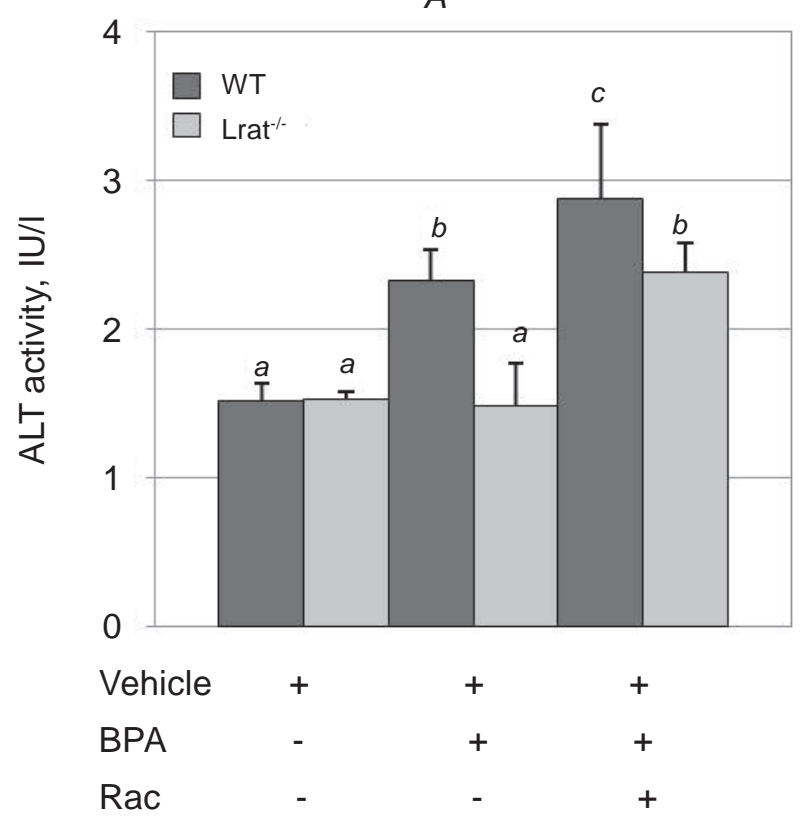

rise in blood serum ALT activity and 5-fold rise hepatic MPO activity, correspondingly (Fig. 1).

These primary biochemical indicators of hepatotoxicity in wild-type animals were corroborated by severe oxidative damage to liver lipids and proteins, which may result either from effects of toxic BPA radicals or from BPA-induced activation of free-radical processes [23]. The most pronounced changes were those of TBARS and protein carbonyl groups, the levels of which rose by twofold and 1.3-times under effect of BPA, correspondingly (Fig. 2, A, B). We also found decreased protein and non-protein thiol levels in comparison to control by 41 and $66 \%$, correspondingly (Fig. 2, $C, D$ ). This oxidative damage to liver biomolecules was the basis of hepatotoxicity onset as evidenced by increased blood serum ALT and hepatic parenchyma MPO activity (Fig. 1).

Conversely, $\mathrm{Lrat}^{-/}$animals did not have statistically significant changes in levels of TBARS, protein carbonyl groups and protein and non-protein thiol groups in comparison to control group of wild-type animals that were not subjected to BPA administration (Fig. 2). It is obvious that lack of hepatic retinoid stores (as retinyl esters) provides for defense against oxidative damage to liver biomolecules. Administration of 3000 IU of vitamin A to such animals caused decrease in protein and non-protein thiols, increase in TBARS and protein carbonyl groups, which indi-

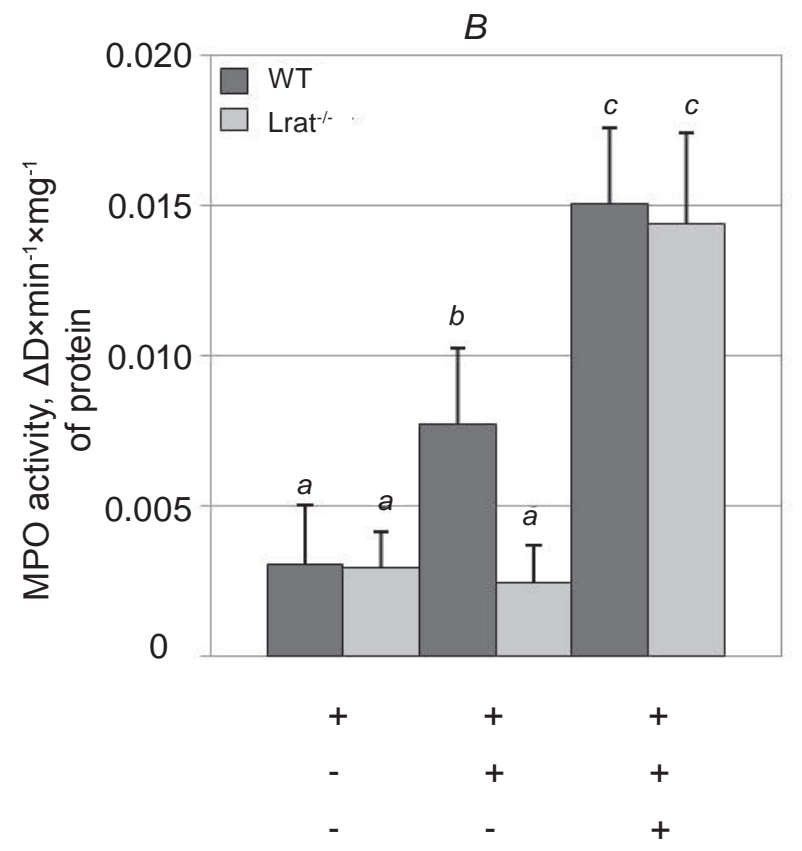

Fig. 1. Blood serum alanine aminotransferase (A) and hepatic parenchyma myeloperoxidase (B) activity in experimental animals. Vehicle - corn oil; BPA - bisphenol A; Rac - retinyl acetate. Here and for Fig. 2 the data indicated by indexes $(a, b, c)$ differ statistically significant, $P<0.05$ 

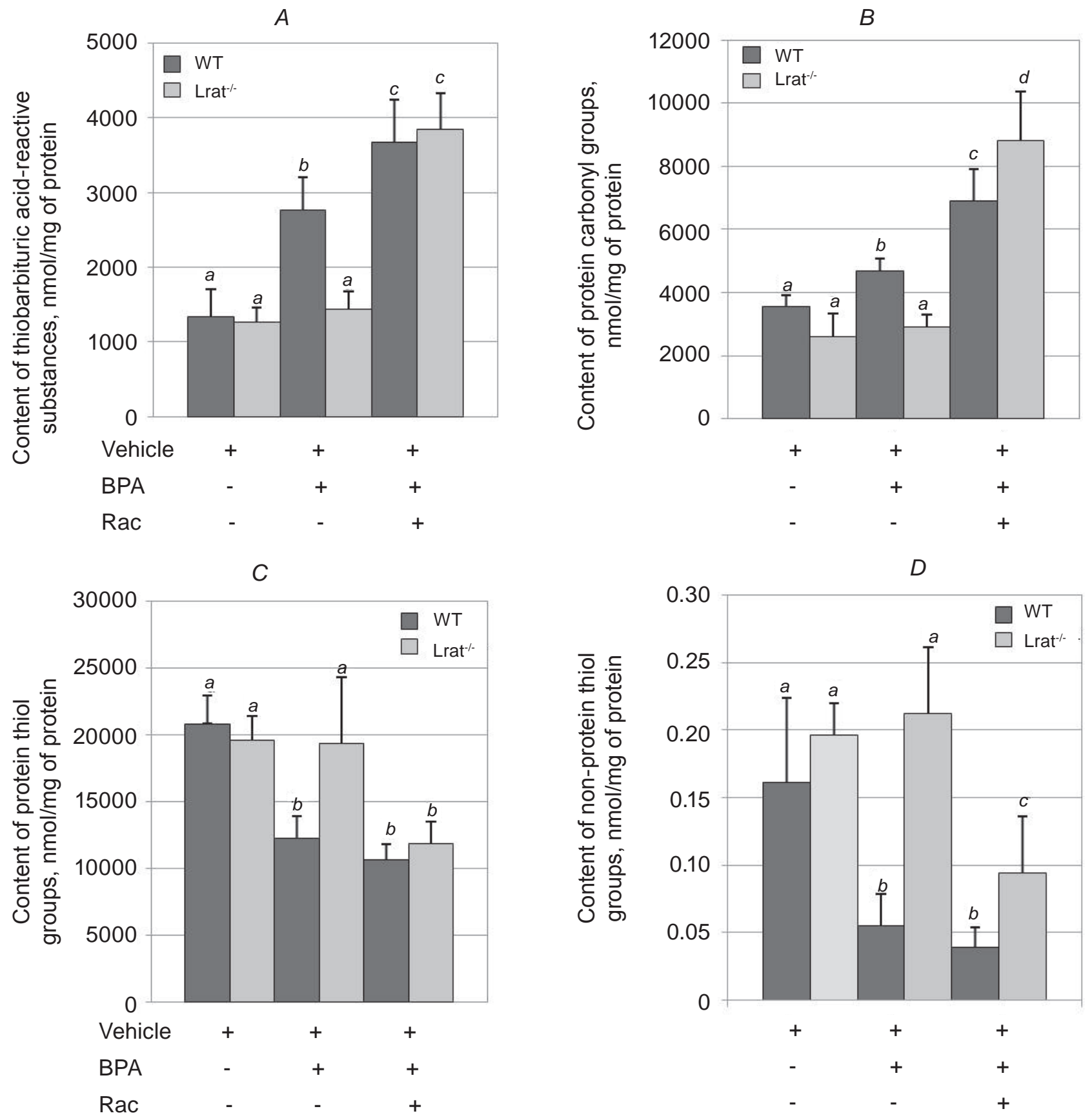

Fig. 2. Content of products of oxidative degradation of cellular biomolecules in liver. A-content of thiobarbituric acid-reactive substance; $B$ - protein carbonyl groups; $C$ - protein thiol groups; $D$-non-protein thiols

cates free-radical damage to liver biomolecules associated with availability of retinoids (Fig. 2). Moreover, the simultaneous administration of BPA and very high doses of retinyl acetate resulted in even more pronounced damage to liver protein and lipid components in wild-type animals (Fig. 2). It needs to be mentioned that administration of $3000 \mathrm{IU}$ of vitamin A to wild-type and knockout animals without administration of BPA was not associated with significant changes in the investigated parameters, which remained at control levels (data not shown).

The effects indicating relation BPA toxicity to retinoid availability have to be mediated by their ability to affect components of liver detoxification system $[9,10]$, and especially CYPs - the key enzymes of phase I detoxification. The sped up metabolism of BPA aimed to detoxify it paradoxically leads to production of higher amounts of its toxic 
metabolites - 2- or 3-OH-BPA and quinone forms [25], which in turn potentiates BPA hepatotoxicity. We conceivably observed this under administration of very high doses of vitamin A. Lack of retinoids provides for organism's tolerance to BPA-induced hepatotoxicity, while administration of very high vitamin A doses aggravates the hepatotoxic processes.

A similar effect was detected in our previous studies on the model of thioacetamide-induced hepatotoxicity. In that model, similarly, the lack of endogenous stores of retinoids in animals provided for endurance against acute thioacetamide-induced liver lesions, and additional supplementation with alimentary retinoids potentiated the hepatotoxicity of the xenobiotic [24]. The modulating effects of retinoids were demonstrated on models of $\mathrm{CCl}_{4}$ - and acetaminophen-induced hepatotoxicity. In works [25-27] it has been demonstrated that additional supplementation with retinoids may aggravate processes associated with toxic lesions of the liver induced by administration of xenobiotics.

The results of this work and literature analysis [8] allow to uncover common patterns and suggesting that retinoids are actively involved in processes of in vivo biotransformation of xenobiotics. This interaction has to rely on realization of genomic effects of retinoids via their nuclear receptors, primarily through retinoid participation in regulation of metabolic detoxification pathways [8]. On the other hand, the results of this and other studies [24] indicate that retinoid-dependent potentiation of biotransformation of xenobiotics is not always a positive result in itself, as it may generate more toxic intermediates, which eventually will aggravate the hepatotoxic effects. Our results demonstrate that this problems needs to be investigated in detail, including perspectives for analysis of expression and activity of specific elements of cellular detoxification system, features of free-radical damage to cellular compartments and activity of components of antioxidant system. The involvement of retinoids in processes of detoxification, additionally, will lead do depletion of these essential compounds and will result in marginal vitamin A deficiency associated with unbalancing of other retinoid-dependent metabolic pathways.

We have therefore established that lack of hepatic retinoid stores provides for organism's endurance against BPA-induced liver lesion. Additional supplementation with retinoids potentiates the hepatotoxic effects of BPA resulting from oxidative damage to hepatic biomolecules, evidenced by increased blood serum ALT activity and hepatic parenchyma MPO activity. Since these indicators of hepatotoxicity are absent under lack of hepatic retinyl esters and start to appear under normal or higher vitamin A doses, we conclude that retinoid content is one of the factors determining BPA hepatotoxicity.

\section{ГЕПАТОТОКСИЧНІСТЬ БІСФЕНОЛУ А В УМОВАХ РІЗНОЇ ЗАБЕЗПЕЧЕНОСТІ ОРГАНІЗМУ РЕТИНОЇДАМИ}

\section{I. О. Шмараков, В. Л. Борщуовецькка, Л. П. Іваніщук, М. М. Марченко
Чернівецький національний університет імені Юрія Федьковича, Україна; e-mail: igor.shmarakov@gmail.com

Класичні токсичні ефекти бісфенолу А (2,2-біс(4-гідроксифеніл)-пропан, ВРА) in vivo як ксеноестрогену детально охарактеризовано, проте молекулярні механізми індукованої ВРА гепатотоксичності залишаються не до кінця розкритими. У роботі проведено біохімічну оцінку індукованої ВРА гепатотоксичності в умовах різної забезпеченості організму ретиноїдами. Показано, що відсутність ретиноїдів як основної запасаючої форми вітаміну А забезпечує толерантність організму до індукованого ВРА ураження печінки. Додаткове надходження ретиноїдів посилює гепатотоксичні ефекти бісфенолу А, що виявляється у підвищенні показників оксидативного пошкодження ліпідів, протеїнових та непротеїнових тіолів печінки і у підвищенні активності аланінамінотрансферази в сироватці крові та активності мієлопероксидази в паренхімі печінки. Відсутність ознак гепатотоксичності у разі недостатності ретиноїдів та їх присутність за нормальної чи надлишкової кількості вітаміну А свідчать, що забезпеченість ретиноїдами є одним із факторів, які залучені у гепатотоксичні ефекти ВРА.

К л ючові слова : ретиноїди, бісфенол А, гепатотоксичність, ксенобіотики. 


\section{ГЕПАТОТОКСИЧНОСТЬ БИСФЕНОЛА А В УСЛОВИЯХ РАЗЛИЧНОЙ ОБЕСПЕЧЕННОСТИ ОРГАНИЗМА РЕТИНОИДАМИ}

\author{
И. А. Шмараков, В. Л. Борщзовецүкая, \\ Л. П. Иванищук, М. М. Марченко \\ Черновицкий национальный университет \\ имени Юрия Федьковича, Украина; \\ e-mail: igor.shmarakov@gmail.com
}

Классические токсические эффекты бисфенола А (2,2-бис(4-гидроксифенил)-пропан, BPA) in vivo в качестве ксеноэстрогена детально охарактеризированы, однако молекулярные механизмы ВРА-индуцированной гепатотоксичности остаются не до конца раскрытыми. В работе проведена биохимическая оценка ВРАиндуцированной гепатотоксичности в условиях различной обеспеченности организма ретиноидами. Показано, что их отсутствие в печени как основной запасающей формы витамина А обеспечивает резистентность организма к ВРАиндуцированному поражению печени. Дополнительное поступление ретиноидов усиливает гепатотоксичные эффекты ВРА, что проявляется в высоких показателях окислительного повреждения липидов, протеиновых и непротеиновых тиолов печени и в повышении активности аланинаминотрансферазы в сыворотке крови и активности миелопероксидазы в паренхиме печени. Отсутствие признаков гепатотоксичности при недостаточности ретиноидов и их присутствие при нормальном или избыточном количестве витамина А свидетельствуют, что обеспеченность ретиноидами является одним из факторов, определяющих гепатотоксичность бисфенола А.

К л ю че вы е сл о в а: ретиноиды, бисфенол А, гепатотоксичность, ксенобиотики.

\section{References}

1. Pandit A, Sachdeva T, Bafna P. Drug-Induced Hepatotoxicity: A Review. JAPS. 2012; 2(5): 233-243.

2. Maes M, Vinken M, Jaeschke H. Experimental models of hepatotoxicity related to acute liver failure. Toxicol Appl Pharmacol. 2016; 290: 86-97.

3. Nahar MS, Liao C, Kannan K, Dolinoy DC. Fetal liver bisphenol A concentrations and biotransformation gene expression reveal variable exposure and altered capacity for metabolism in humans. $J$ Biochem Mol Toxicol. 2013; 27(2): 116-123.

4. Richter CA, Birnbaum LS, Farabollini F, Newbold RR, Rubin BS, Talsness CE, Vandenbergh JG, Walser-Kuntz DR, vom Saal FS. In vivo effects of bisphenol A in laboratory rodent studies. Reprod Toxicol. 2007; 24(2): 199224.

5. Kundakovic M, Champagne FA. Epigenetic perspective on the developmental effects of bisphenol A. Brain Behav Immun. 2011; 25(6): 1084-1093.

6. Wang W, Jiang C, Zhu L, Liang N, Liu X, Jia J, Zhang C, Zhai S, Zhang B. Adsorption of bisphenol A to a carbon nanotube reduced its endocrine disrupting effect in mice male offspring. Int J Mol Sci. 2014; 15(9): 1598115993.

7. Xia W, Jiang Y, Li Y, Wan Y, Liu J, Ma Y, Mao Z, Chang H, Li G, Xu B, Chen X, Xu S. Early-life exposure to bisphenol a induces liver injury in rats involvement of mitochondria-mediated apoptosis. PLoS One. 2014; 9(2): e90443.

8. Shmarakov IO. Retinoid-xenobiotic interactions: the Ying and the Yang. Hepatobiliary Surg Nutr. 2015; 4(4): 243-267.

9. Howell SR, Shirley MA, Ulm EH. Effects of retinoid treatment of rats on hepatic microsomal metabolism and cytochromes P450. Correlation between retinoic acid receptor/retinoid $\mathrm{x}$ receptor selectivity and effects on metabolic enzymes. Drug Metab Dispos. 1998; 26(3): 234-239.

10. Brtko J, Dvorak Z. Role of retinoids, rexinoids and thyroid hormone in the expression of cytochrome p450 enzymes. Curr Drug Metab. 2011; 12(2): 71-88.

11. Balmer JE, Blomhoff R. Gene expression regulation by retinoic acid. J Lipid Res. 2002; 43(11): 1773-1808.

12. Guide for the care and use of laboratory animals. Washington D. C.: National Academies Press, 2011. 246. p.

13. National Toxicology Program U.S. Department of Health and Human Services. Center For The Evaluation of RisksTo Human Reproduction; NTP-CERHR Monograph on the Potential Human Reproductive and Developmental Effects of Bisphenol A.: NIH Publication, 2008. 599 p. 
14. O'Byrne SM, Wongsiriroj N, Libien J, Vogel S, Goldberg IJ, Baehr W, Palczewski K, Blaner WS. Retinoid absorption and storage is impaired in mice lacking lecithin:retinol acyltransferase (LRAT). J Biol Chem. 2005; 280(42): 3564735657.

15. Wongsiriroj N, Piantedosi R, Palczewski K, Goldberg IJ, Johnston TP, Li E, Blaner WS. The molecular basis of retinoid absorption: a genetic dissection. J Biol Chem. 2008; 283(20): 1351013519.

16. Shmarakov IO, Marchyshak TV, Borschovetska VL, Marchenko MM, Tkachuk ZY. Hepatoprotective activity of exogenous RNA. Ukr Biochem J. 2015; 87(4): 37-44.

17. Ohkawa H, Ohishi N, Yagi K. Assay for lipid peroxides in animal tissues by thiobarbituric acid reaction. Anal Biochem. 1979; 95(2): 351358.

18. Levine RL, Garland D, Oliver CN, Amici A, Climent I, Lenz AG, Ahn BW, Shaltiel S, Stadtman ER. Determination of carbonyl content in oxidatively modified proteins. Methods Enzymol. 1990; 186: 464-478.

19. Horyachkovskiy A. Clinical Biochemistry in laboratory diagnostics: A Reference Guide. Odessa: Ecology, 2005. 616 p.

20. Murphy ME, Kehrer JP. Oxidation state of tissue thiol groups and content of protein carbonyl groups in chickens with inherited muscular dystrophy. Biochem J. 1989; 260(2): 359-364.
21. Waterborg JH, Matthews HR. The Lowry method for protein quantitation. Methods $\mathrm{Mol}$ Biol. 1994; 32: 1-4.

22. Schmidt J, Kotnik P, Trontelj J, Knez Ž, Mašič LP. Bioactivation of bisphenol $\mathrm{A}$ and its analogs (BPF, BPAF, BPZ and DMBPA) in human liver microsomes. Toxicol In Vitro. 2013; 27(4): 12671276.

23. Hassan ZK, Elobeid MA, Virk P, Omer SA, ElAmin M, Daghestani MH, AlOlayan EM. Bisphenol A induces hepatotoxicity through oxidative stress in rat model. Oxid Med Cell Longev. 2012; 2012: 194829.

24. Shmarakov IO, Borschovetska VL, Marchenko MM, Blaner WS. Retinoids modulate thioacetamide-induced acute hepatotoxicity. Toxicol Sci. 2014; 139(2): 284-292.

25. Rosengren RJ, Sauer JM, Hooser SB, Sipes IG. The interactions between retinol and five different hepatotoxicants in the Swiss Webster mouse. Fundam Appl Toxicol. 1995; 25(2): 281292.

26. Bray BJ, Goodin MG, Inder RE, Rosengren RJ. The effect of retinol on hepatic and renal drugmetabolising enzymes. Food Chem Toxicol. 2001; 39(1): 1-9.

27. Bray BJ, Rosengren RJ. Retinol potentiates acetaminophen-induced hepatotoxicity in the mouse: mechanistic studies. Toxicol Appl Pharmacol. 2001; 173(3): 129-136.

Received 03.02.2016 